\title{
Internationalizing the Association for Business Communication: A Long Journey, One Step at a Time
}

\section{James M. Dubinsky}

Executive Director of Association for Business Communication (ABC), Virginia Polytechnic Institute and State University, Blacksburg, VA, USA

The Association for Business Communication (ABC) began its shift away from a US-centric perspective in the mid-1980s, and the journey toward internationalization has been a long one. In 1985, ABC removed the modifier of "American" from its name, becoming an association with no boundaries, at least nominally (Locker, 1998, p. 16).

By 1997, after "a decade of effort to internationalize the organization" (Victor, 2009, p. 67), ABC felt confident enough to expand beyond its North American borders. It added regions outside of North America: Central and South America, Mexico, and the Caribbean; Asia and the Pacific; and Europe, the Middle East, and Africa. These regions and their members have contributed tremendously to ABC's mission as "an international, interdisciplinary organization committed to advancing business communication research, education, and practice" (https:// businesscommunication.org).

In 2008, ABC published a strategic plan listing four goals, including one to "ensure a deep level of internationalization throughout the organization" (Dubinsky, et al., 2008). In 2011, three years into the plan, $\mathrm{ABC}$ hosted its annual international conference in Montreal, Canada. Two years later, ABC held its annual conference in Dublin, Ireland, the first one outside of North America. The next logical step is to host an event in our Asia and the Pacific region.

This is an Open Access article distributed under the terms of the Creative Commons Attribution Non-Commercial License (http://creativecommons.org/licenses/ by-nc/4.0/) which permits unrestricted non-commercial use, distribution, and reproduction in any medium, provided the original work is properly cited. Copyright (c) 2019 Korean Association for Business Communication.
With the advent of a conference in Asia Pacific, I have been thinking about the organization I serve and its history, with an eye toward the trajectory of business communication research from an international perspective. As I examine the work of ABC's thought leaders in the past 20 years, I am impressed by the amount and variety of scholarly work. Because space is limited, I have narrowed my scope to a question that one of my intellectual and association mentors raised in 1998: the role of the Association (and thus of its journals) in the shaping of the discipline of business communication (Locker, 1998). Specifically, I am focusing on the effect that the move toward internationalization in the Association has had on the research of the field. To that end, this article highlights three historical moments that capture critical inquiry in our discipline from an international perspective and offers discussion of these events that, I believe, can be useful in outlining a research agenda for a conference in Asia Pacific:

1. In May 1999, ABC held its first European regional conference in Helsinki, Finland. Six months later, the organizers published a series of short articles in Business Communication Quarterly to explain their research rationale.

2. In October 2006, a five-person panel, all research award winners, focused on "Business Communication Research: Past, Present, and Future." The presenters' remarks were summarized by two ABC scholars, Jim Suchan (United States) and Mirjaliisa Charles (Finland) in the Journal of Business Communication.

3. In 2018, KABC published the first issue of BCRP (Business Communication Research and Practice). In that issue, Ber- 
tha Du-Babcock, who has served $\mathrm{ABC}$ as a regional vice president for its Asia and the Pacific region and as its President, published "Business Communication Research and Theory Development in Asia: Past, Present, and Future Prospects."

\section{December 1999: $A B C$ in Europe (Business through Language} and Communication)

The May 1999 conference was more than a milestone in ABC's history; it also marked a shift towards understanding a duality of how "national cultures, professional cultures, or discourse cultures" impact the nature of work that is tempered by a "quest for universals" required by a global business environment (Charles, 1999, p. 107). In the 1990s, business and business communication were booming (St. John, 1996); the Internet shortened distances between locations and made communication virtually instantaneous. One of the conference organizers used the term "interspecialism" to "link up the two sides of the duality: business communicators communicat[ing] as specialists in their own fields-with all the cultural and other differences that implies-yet producing constructs that transcend these differences" (Rogers, 1999, p. 108).

The conference featured six presentation tracks:

- International and intercultural aspects of business communication

- Analyzing professional interaction

- Teaching language through business content

- Language needs in business

- New technologies for business communication

- Evaluation of international skills (Yii-Jokipii, 1999, p. 104)

The tracks and the theme were thoroughly debated and interrogated. While the organizers recognized their limitations, they also recognized their value, which I return to in the conclusion.

\section{October 2006: Business Communication Research: Past, Present, and Future (Panel)}

By 2006, ABC had convened several conferences in its European and Asia Pacific regions. That year, on the $\mathrm{ABC}$ Board's agenda was the future of our growing organization, which proved formative, ultimately leading to the development of the first strategic plan (mentioned earlier) in more than 15 years. That same year, $A B C$ 's researchers were wrestling with the impacts of the changing global environment on the discipline. The panel at that same conference, chaired by Suchan and Charles (2006), offered a snapshot from five scholars who won $\mathrm{ABC}$ researcher and best publication awards. These scholars brought a range of perspectives: Poncini was the regional vice president for the
Europe, Africa, and Middle East region. Rogers had been and continued to teach and consult in the Asia Pacific region, and Forman taught primarily at the MBA level.

Prior to the panel, the five scholars were asked to consider baseline questions ranging from "What new communication knowledge has [been] created?" to "What areas can we look to for interesting theory, models, and conceptual frameworks to expand our own and our important stakeholders' understanding of communication?" Their responses described the importance of research methods such as ethnography, case analysis, and genre studies, while emphasizing "how workplace communication [has] come alive [as the result of] the myriad organizational and situational factors that influence how texts are created, interpreted, and used" (Suchan \& Charles, 2006, p. 391).

The panelists' concerns about professional and disciplinary identity led them to embrace the nature of our field as "multi- or interdisciplinary" (p. 393). While they recognized "frameworks that enable practitioners to see more clearly the organizational situations in which they are embedded" (p. 394), Poncini's call for "research in multicultural and multilingual settings" (p. 395) pushed the discussion further into an international arena. By focusing on workplace activities and research methodologies, they pointed out the necessity of better understanding praxis by conducting research within organizations and by so doing, illuminated strategies used by practitioners, strategies teachers can pass on to students.

\section{January 2018: $B C R P$, A Step forward for $K A B C$ and for Business Communication}

The publication of $B C R P$ as an English-language-only journal marked another significant step, not only for the Korean Association for Business Communication (KABC) but also for the entire discipline. As its editors explained (Chang \& Kim, 2018), "the decision means that the ultimate goal is not to stay at a domestic level but to build a reputation at the global level" (p. 2).

The lead article, written by Bertha Du-Babcock, a recent past president of $A B C$ and winner of ABC's 2018 Distinguished Publication Award, highlights the organization's growing interconnectivity and global nature. In this essay, Du-Babcock offers a review of business communication research and theory in Asia over the past two decades by focusing on "three streams of culture, language, and international business" (p. 5). I cannot do justice to her article in a paragraph, but her discussions of cultural influence on such issues as conflict management, language-based communication zones, and the development of business English as a lingua franca all point to back to Rogers' discussion of "interspecialism" and forward to a need to "develop closer connections between research, theory building, and prac- 
tice... [with a goal of] a unified, comprehensive, and integrated theory" that is more akin to an "orchard" than a "jungle" (p. 14).

\section{Reflection and Next Steps}

As Du-Babcock indicates, the critical importance of Asia cannot be understated, nor can the essential challenge of communicating across cultures. Thus, the foundational track of a $21^{\text {st }}$ century international conference in business communication could well be the same one used at ABC's first truly international event at the close of the $20^{\text {th }}$ century: International and intercultural aspects of business communication. We need to understand the ways businesses are operating to prepare students for an international, and therefore intercultural, world, examining how our discipline understands and explains genre, intra- and interorganizational communication and the impact of developments such as social media and virtual collaboration tools. We must, as Du-Babcock (2006) explained, move beyond a focus "written by American authors and geared toward native English-speaking students" (p. 254) and towards how to "cope with and communicate in this increasingly complex and diverse global, multidisciplinary communication environment" (p. 257).

The next four tracks of the 1999 Helsinki conference all point to the baseline need to study communication in situ, to understand what businesses are doing, the kinds of genres they are using or adapting, and how technologies and new media are impacting their practice. These or similar tracks, informed by Poncini's focus on research in workplaces, remain critical, as would a discussion of the challenges researchers face when trying to gain access to organizations or corpora of data in/from the workplace. We also must foreground research methodologies and how our scholars use them to analyze such environments or corpora.

The final track, "Evaluation of international skills," also remains relevant. However, this evaluation must also include a review of our students' language needs. For many years our colleagues who teach and publish in English for Special Purposes (ESP) journals have called for "needs analysis and syllabus design" (Chan, 2018, p. 27). Our colleagues in Europe (Louhiala-Salminen \& Kankaanranta, 2012; Louhiala-Salminen, Kankaanranta, \& Charles, 2005; Zagan-Zelter \& Zagan-Zelter, 2010) and Asia (Chan, 2018; Du-Babcock, 2018) have articulated the concept of Business English as a Lingua Franca (BELF); it needs to be further explicated and shared with colleagues who teach almost exclusively in English speaking countries, and it needs to be situated more clearly in a relationship with ESP.

As a scholar in crisis communication has explained in All Crises are Global (Pinsdorf, 2004), when crises occur, national frontiers disappear. In our discipline, we have understood this basic premise, but we still have a long way to go when it comes to adapting practices and pedagogy. For our upcoming conference, we should consider interrogating and reassessing all elements of our discipline regarding the impact of this dissolution of boundaries, one that began when we eliminated "American" from our Association's name and discipline more than 30 years ago.

Business communication is indeed "essential for growth and success in business" (Suh, 2018, p. 51), and, despite what seems as some retrenchment with nationalist movements, the global business economy is here to stay. These three "moments" demonstrate a recognition by our scholars to study the complexity of everyday practice in a global business environment and to develop research agendas that inform our teaching. As we plan for an event in Asia, we need to follow the trajectory of the work that has gone before and, as Du-Babcock has done, focus on the future.

\section{References}

Chan, C. S. C. (2018). Proposing and illustrating a research-informed approach to curriculum development for specific topics in business English. English for Special Purposes, 52, 27-46.

Chang, H., \& Kim, J. A. (2018). A step forward for KABC. Business Communication Research and Practice, 1(1), 1-3.

Charles, M. (1999). Developing the conference theme and tracks. Business and Professional Communication Quarterly, 62(4), 105-108.

Du-Babcock, B. (2006). Teaching business communication: Past, present, and future. International Journal of Business Communication, 43(3), 253-264.

Du-Babcock, B. (2018). Business communication research and theory development in Asia: Past, present, and future prospects. Business Communication Research and Practice, 1(1), 4-17.

Dubinsky, J. M. (2008). The future of ABC: A five-year strategic planning proposal. Nacogdoches, TX: Association for Business Communication. Retrieved from https://www.businesscommunication.org/p/do/sd/ sid $=2255 \&$ fid $=1233 \&$ req $=$ direct

Locker, K. O. (1998). The role of the Association for Business Communication in shaping business communication as an academic discipline. The Journal of Business Communication, 35(1), 14-49.

Louhiala-Salminen, L., Charles, M., \& Kankaanranta, A. (2005). English as a lingua franca in Nordic corporate mergers: Two case companies. English for Specific Purposes, 24(4), 401-421.

Louhiala-Salminen, L., \& Kankaanranta, A. (2012). Language as an issue in international internal communication: English or local language? If English, what English? Public Relations Review, 38(2), 262-269.

Pinsdorf, M. K. (2004). All crises are global: Managing to escape chaos. New York, NY: Fordham University Press. 
Rogers, P. S. (1999). Internationalism, technological innovation, and new associations: Bringing change to business communication research and teaching. Business and Professional Communication Quarterly, 62(4), 108-110.

St. John, M. J. (1996). Business is booming: Business English in the 1990s. English for Specific Purposes, 15(1), 3-18.

Suchan, J., \& Charles, M. (2006). Business communication research: Past, present, and future. The Journal of Business Communication, 43(4), 389-397.

Suh, Y. H. (2018). Business communication with corporate social responsibility. Business Communication Research and Practice, 1(2), 51-53.

Victor, D. (2009). David Victor, 1997. In M. L. Bayless, \& T. L. Austin (Eds.), 75th Diamond Anniversary Keepsake. Nacogdoches,
TX: Association for Business Communication. Retrieved from https://www.businesscommunication.org/p/do/sd/sid=2619\& fid=1429\&req=direct

Yii-Jokipii, H. (1999). Remarks from the first ABC European convention: Business through language and communication. Business Communication Quarterly, 62(4), 104-105.

Zagan-Zelter, D., \& Zagan-Zelter, S. (2010). Teaching business English: A challenge both for students and academics. Procedia Social and Behavioral Sciences, 3, 245-250.

James M. Dubinsky

Department of English, Virginia Polytechnic Institute and State University, 323 Shanks Hall (0112), 181 Turner St. NW, Blacksburg, VA 24061, USA Tel: +1-540-231-1939, E-mail: dubinsky@vt.edu 